\title{
GENETIC ENGINEERING CAN EITHER EXACERBATE OR ALLEVIATE HERBICIDE RESISTANCE
}

\author{
J. GRESSEL
}

\section{Plant Genetics, Weizmann Institute Of Science, Rehovot, Israel}

\begin{abstract}
Sweeping generalizations promulgating dangers of herbicide-resistant crops and "superweeds" rarely meet scrutiny. Engineering resistance to little used, and especially multi-site herbicides can relieve selection pressures for evolution of resistance to the currently sometimes overused herbicide groups (e.g. inhibitors of ALS and ACCase). Engineering resistance to widely-used, single site herbicides into crops, increases evolutionary pressure for resistance. Such transfers could be justified for the control of parasitic weeds, where the alternatives are worse. Engineering resistance into crops that easily interbreed with weeds can sometimes be unwise. The rates of movements of such genes to weeds are unknown but gene transfer could be learnt using innocuous cases. There could still be advantages to resistant crops, without weed danger to other cropping situations (rice/red rice). Rational, case by case risk/cost/benefit analysis must replace irrational fear-striking generalizations, as agriculture can gain from many herbicide-resistant crops.
\end{abstract}

Keywords: herbicide resistance, transgenic crops, gene transfer, superweeds, genetic engineering

\section{INTRODUCTION}

Much misinformation, disinformation and widely inaccurately interpreted correct information has been promulgated about genetically engineered herbicide-resistant crops (cf. Rissler and Mellon 1995), especially by those with an anti-genetic engineering and/or anti-pesticide bias. Not all environmentalists share these radical views (Lewis 1992). We are warned that these crops can lead to the evolution of "superweeds" that will inherit the earth (Kling 1996). Resulting severe political pressures preclude much publicsector research in this area, which affects getting accurate information about the dangers, as well as prevents engineering of crops needing resistance to herbicides where the agrochemical industry sees little profit. The situation is further complicated by wellmeaning scientists who are drawn into the debates, but lack the knowledge to balance the issues, and make scientifically untenable extrapolations from the known data.

Farmers could use less or no herbicide but at what cost and how many will starve? Sustainable agriculture is a wonderful goal; but there are many definitions of sustainability. Most know only the "western" versions; in India sustainability is the ability to increase food production to sustain growing populations. There are alternatives to herbicides. Good crop rotations by themselves lower weed seed banks and pressures, yet many areas have no possible agronomically-meaningful rotations (e.g. the marginal lands where much of the world's wheat is grown), or economically meaningful rotations. Mechanical cultivation can replace much of the herbicide used. In fragile agroecosystems, mechanical cultivation precludes sustainability compared with soil and water conserving, high herbicide, precision no-till. Plant breeding required herbicides to produce high yield index, low stature "green revolution" wheats and rice. We could revert to the tall varieties that compete with weeds, needing less herbicide. How will we feed the populace? What will we do with the useless straw?

This essay analyses where herbicide-resistant crops have value, where their use might be contraindicated, the implications of their use to weed resistance, and needed 
precautions. It considers all biotechnology-derived resistant crops, seeing little difference between mutagenesis-derived imidazolinone-resistant maize and other crops with the same gene introduced.

\section{TRANSFER OF GENES TO WEEDS}

There have been many reports on introgression of crop genes into related weed species, but few from controlled experiments; i.e. they are apocryphal to use a "negative" term or epidemiological to use a "positive" term. They include reports showing that traits bred into cultivated barleys, oats or rice soon appear in the wild weedy species in the same areas. Most have not dealt with herbicide resistance, as the wild species usually have the same spectra of natural herbicide resistances as related crops. Controlled experiments have shown that herbicide resistances can be transferred from crops to wild relatives, but usually resorted to model or artificial systems; hand pollination after emasculation of the weed, male sterility or self incompatibility in the weed, massive amounts of crop pollen, and/or embryo rescue of the rare progeny, that are mostly sterile (Darmency 1994). The epidemiological / apocryphal reports are actually more relevant to risk analysis; they indicate that such transfers can occur in the field, the time until predominance, and the competitive advantage.

There have been rare cases where gene flow from (non-transgenic) crops to weeds has produced weedier weeds. Crops themselves can evolve into weeds (cf Baker 1991; Boudry et al. 1993) and weeds continue to evolve mimicries of crops (Barrett 1983). That does not mean that herbicide resistance per se will make a weed weedier. This depends on the gene and herbicide use patterns. Most studies rating risks of movement do not differentiate between the reports of field transfer and the studies showing it could occur. They do not estimate how long it will take to have resistance introgress and predominate in wild populations vs. how long it would take resistance to evolve by natural selection, vs. the expected commercial lifetime of the herbicide. This abrogates scientific evaluation to politicians, who are most influenced by those bearing an agenda.

The major thesis of this paper is to emphatically state that because of genetic variability of crops and weeds, and chemical variability in herbicides, their effects and modes of action, one cannot make easy generalizations about the risks of resistance transfer. Each case of predicting the risk of introgression must be evaluated on its merits, often after basic biological, genetic and epidemiological studies. More importantly, other issues must be considered:

(1) What is the benefit to food production of having resistance in a certain crop?

(2) What are the implications of having herbicide resistance pass into a weedy species?

It is often assumed that all "superweeds" will be deleterious to agriculture and/or the environment.

\section{Innocuously assaying introgression in the field}

There are ways to ascertain the rapidity of gene movement, without causing lasting damage to agriculture and/or the environment: simply insert a gene for resistance to a rarely used passé herbicide; where there would be little consequence to the herbicide becoming extinct. Another way to establish the rate of transfer of genes is to abolish the double standard; we cannot prevent the use of herbicide-resistant crops where the resistance is "natural". ALS-level resistant maize and rape from tissue culture selection were acceptable (after registration for that crop). Triazine-resistance, laboriously transferred from wild brassica into oilseed rape (Souza Machado et al. 1982) was also allowed. Similar genes introduced transgenically are verboten in many countries and under scrutiny elsewhere. At present, when a weed becomes resistant to any of these herbicides it is not known whether it evolved naturally or was introgressed through pollination. The highly mutable ALS gene ( $\mathrm{ca} .10^{-6}$ resistance in populations) quickly appears in weeds. Engineering the same gene with either a two base change coding difference from the natural gene, or with different introns, allows differentiating mutation from introgression.

In the case of triazine resistance, there could be added benefits. The trait is maternally inherited, so one might assume it will never transfer. Maternal inheritance is not absolute; $0.2 \%$ pollen transfer was found with genetic markers.

The many factors that must be assessed in ascertaining risk include: 
(a) Would the newly-resistant weed really be weedy once herbicide use is stopped? Brachypodium distachyon evolved triazine resistance along roadsides. When triazine usage stopped, it reverted to being a minor ruderal species (Gressel and Kleifeld 1995). If the wild type was never weedy, why expect the resistant biotype to be more fit? Too often one forgets that many ruderal species lack weedy properties and resistance to a herbicide is unlikely to tip the balance. Indeed, if the herbicide is used in the transgenic crop, then susceptible weeds growing in its midst will not introgress the resistant genes - dead weeds don't have sex. The genes could introgress into nearby unsprayed weeds. Seed set on emasculated plants from oilseed rape was measured $1.5 \mathrm{~km}$ from pollen source (Timmons et al. 1996); can the progeny compete, or survive in feral populations without selector? Without emasculation resistant pollen fertilized $24 \%$ of plants in the immediate vicinity but $<0.017 \%$ just 10 meters away.

(b) How often is the weed in question a weed in other crops, where the same herbicide group is used? Will the rotational herbicides in the rotational crops control resistant weeds?

(c) Generalizations about cross resistance within herbicide groups are often moot because of the gene used. The Pseudomonas gene coding for a cytochrome P450 conferring metabolic resistance to 2,4-D does not confer resistance to closely related, often agronomically interchangeable, MCPA (Streber and Willmitzer 1989). MCPA could control volunteer weeds (the previous season's transgenic crop) or weeds introgressing the gene. Conversely, the developers of ALS and ACCase target based resistances for every crop in rotation, whether biotech derived or having chemical selectivities, are hastening evolution of resistant weeds. Resistance has evolved to many herbicide chemistries that were listed as low risk (chloroacetamides, thiocarbamates, paraquat, glyphosate) but the persistence of the herbicides or of farmers to continuously use them, have engendered the predictable.

There is much place for engineering resistance to lesser used herbicides. Expanding their use decreases pressure on heavily used groups. Not too much is done with the published genes for resistance to 2,4-D, phenmedipham, dalapon, asulam, and even bromoxynil. Genes for resistance to many other herbicide groups have not been described. There is a fixation on glyphosate, glufosinate and ALS. ACCase resistance is not being developed transgenically, but ACCase-resistant maize adds another crop to rotations, quickening evolution of resistant weeds.

(d) Does the herbicide resistance transgene provide traits that can increase fitness when the herbicide is not used? An unequivocal "no" is hard to provide; an alien gene metabolizing the herbicide might have other substrates, supplying other traits. Herbicide resistance supplies less feral fitness advantage than disease or insect resistance (Karieva et al. 1996). As long as the weed can be controlled by other means, the unpredictables are unlikely to lead to Frankensteinish superweeds. Modified target sites of the herbicide must be less fit than the susceptible wild type or they would be the wild type. Continual monitoring for newly-resistant weeds is always called for; not just those evolving from introgression with resistant crops. It is easier to eliminate nascent resistant foci, than huge areas after spread (Moody and Mack 1988).

(e) Are the wild interbreeding species near the crops? Transgenic ALS-resistant sunflowers for controlling broomrape were refused to European and Israeli researchers by the developers because "the species crosses with wild sunflowers". Such was the fear of "what would detractors say?" that it was futile to explain that the nearest weedy wild relatives were $8000 \mathrm{~km}$ away, and sunflower pollen is short lived. Conversely, engineering glufosinate resistance into domestic Avena (Somerset al. 1992) where interbreeding wild oats is a problem was inexcusable when other selectable markers could have been used (Gressel 1992).

(f) Do the weed and crop have overlapping flowering times? Otherwise, mating is complicated.

(g) Is the weed self incompatible, preferring foreign pollen, enhancing chance meetings? Self pollinated species transfer genes more slowly. 
(h) Is the resistant pollen more or less competitive than con-specific pollen? Pollen competition in some cases is exceedingly strong, and unfitnesses from resistance and being of another species statistically delay gene transfer (Charlesworth 1988; Stephenson et al. 1988 ; Mulcahy and Mulcahy 1987).

(i) How easily can interspecific barriers be overcome? It was considered to be "highly likely" that genes will introgress from cultivated barleys to Hordeum glaucum (Sindel, 1997), while attempts to transfer paraquat resistance from $\mathrm{H}$. glaucum to cultivated barleys proved futile (Islam and Powles 1991). Likewise, it was considered likely that genes from potato will cross into other Solanum species (Sindel 1997). The reciprocal was possible by protoplast fusion (Gressel et al.1989) but there have been no successes in crossing potato with anything but Andean Solanum spp (Eijlander and Stiekema 1994).

\section{CASE ASSESSMENTS}

The best way to discuss benefits and risks is by analyzing questionable cases. They illustrate the important of case assessment where wild weedy relatives exist.

\section{Oilseed raping wild weeds?}

Many were surprised that the Canadian government allowed the field use of glyphosate, glufosinate (and soon bromoxynil)-engineered transgenic oilseed rapes despite the known introgression of herbicide-resistant genes into weeds, including problematic Brassica campestris, (e.g. Mikkelsen et al. 1996; Kerlan et al. 1993; Lefol et al. 1996). The opposite has also been occurring (e.g. McMullan et al. 1994); deleterious weed genes introgress into oilseed rape, lowering yield and oil quality. A major use of herbicide-resistant oilseed rape is to control wild relatives. The authorities did not accept the double standard; ALS-R rape from mutagenesis had been on the market. The decision allows unrestricted field cultivation, while noting the likelihood of introgression, and stating that the worst case would be the loss of glyphosate to control such weeds (Anonymous 1995). The decision stated that introgression would not increase weediness of crop or related weeds, partly based on release studies by Crawley et al. (1993). They did not require two safeguards that might have lowered the risk of transfer to B. campestris, the weediest of the related species (Holmet al. 1997), and the one species with demonstrated field transfer of genes (Mikkelson et al. 1996). Oilseed rape (B. napus) is an ancient allopolyploid between B. oleracea (CC genome) and $B$. campestris (AA). If only transgenic plants bearing resistance on the $\mathrm{C}$ genome were used, resistance could transfer to campestris only by rare homoeologous pairing. Glyphosate resistance is coded on two genes in a tandem construct; one for modified target and the other for degrading the herbicide. Resistance transfer would be delayed if each were inserted on separate $\mathrm{C}$ chromosomes, requiring two independent transfers. Whether fortuitously or by intent, the glufosinate and glyphosate resistances for Canada are on the safer C genome, whereas the resistance that introgressed described above, was on the $\mathrm{A}$ genome (R.K. Downey pers. comm.). The question of how quickly resistance will move from B. napus to B. campestris may be moot, as Polish rape (B. campestris) with these herbicide resistance genes will soon be released (R.K. Downey pers. comm.). In this locale, they do not consider transfer to the con-specific weed a problem, but the crop as a volunteer weed could become a problem, especially if it becomes multiply resistant to all four herbicides introduced in various varieties. What if 2,4-D resistance were also engineered in, or evolved in, Polish rape? Nothing would be left to control it in most plains crops.

Both industry and growers should want to know how quickly and to what extent to expect introgression. This could as described above by assaying transgenic ALS resistance and also with triazine resistance, improving the crop. The triazine resistance gene coding an amino acid 264 transversion from serine to glycine in oilseed rape (SouzaMachado 1982), is highly unfit (Gressel and Ben-Sinai 1988). Reciprocal crosses were always less productive with triazine resistant female parents (Beversdorf et al. 1988). Yet, they are grown in Australia, where oilseed rape gene transfer to wild species is considered "high risk" (Sindel 1997), (but this isn't transgenic). The amino acid 264 transversion serine to threonine that evolved in potato is more fit than serine to glycine 
(Smedaet al. 1993) and should increase yields if transformed into rape chloroplasts. The risk would be more competitive brassica weeds, in the highly unlikely event that the gene moves. As the triazines are becoming passe', the consequences of the infinitesimal are minimal.

\section{Wheat - a crop in dire straits}

Wheat is often cultivated where few other cash crops are grown, precluding widespread rotations. The high yield index, large ear, short stature varieties are wimpish at competing with weeds and can rarely be cultivated without cost-effective herbicides. Minimum tillage systems requiring more herbicides fit fragile wheat agroecosystems. Unlike most crops, wheat has one major system to detoxify herbicides-cytochrome P450 monooxygenases. Grass weeds have evolved morphological and phenological mimicries to wheat for 6000 years (Barrett 1993). They recently evolved biochemical mimicries to overcome wheat herbicides by upping their P450s, often conferring resistances to wheatselective herbicides unrelated to the selector and never used before (Gressel 1988; Moss, 1992; Powles and Holtum 1994; Malik and Singh 1995; Singh et al. 1997). Such resistances cover $40 \%$ of Australian wheatlands and millions of hectares in India. Nonchemical alternatives raise production costs and/or lower the area in wheat, jeopardizing food supplies.

The immediate answer is to engineer resistances to inexpensive graminocides. Because there is too little profit from wheat seeds or generic herbicides, it must be engineered by the public sector. Glufosinate resistance has been engineered into wheat, more as a marker gene than for utility. It is a safe herbicide to use, but expensive to manufacture (via dangerous organophosphorus intermediates). Glyphosate resistance has been engineered into wheat and field tested for the niche market of hybrid wheat, where it is less needed.

There are no weedy relatives of wheat where it evolved, although there are many related ruderal species. They have not introgressed traits from nearby wheats, unlike weedy barleys from cultivated barley in the same area. Gene transfer was possible in the greenhouse to a weedy U.S.Aegilops cylindrica, using embryo rescue (Mallory-Smith et al. 1996), and more recently without embryo in the field (Mallory-Smith, pers. comm.). This does not mean eschewing herbicide-resistant wheat in America, just that more transformants must be tested. Wheat has three parallel genomes from progenitors, $\mathrm{A}, \mathrm{B}$ and D. The weed has genomes $\mathrm{C}$ and D. Crosses with each of the seven wheat D genome monosomics shows whether the transgene is on a D chromosome. Only A and $\mathrm{B}$ transgenics should be released as a safety precaution against the unlikely.

\section{Parasitic weeds}

The parasitic flowering Orobanche and Striga species infest $>100 \mathrm{M}$ hectares of African and Mediterranean crops, limiting where crops can be grown without devastation. Multi-millions lose half their crops to these parasites. Selective herbicides rarely control the underground stages when they sap the crop. Methylbromide is used to rid soil of their seeds in high value vegetable crops. The parasites remove "only" water, mineral, and sugars from the crops. It was posited that crops with target site resistance to translocated herbicides that affect parasite pathways would be effective in controlling these pests (Gressel 1992). Indeed, transgenic plants with resistance to herbicides affecting the pathways leading to either branch chain or aromatic amino acids, as well as to folic acid allowed parasitic weed control (Joel et al. 1996; Abayoet al. 1996; Surov et al. 1997). Small amounts were sufficient, as the sprayed herbicides bioaccumulate in the rootattached parasites. Less herbicide can be applied near (Abayoet al. 1996) or on crop seed (Gressel and Joel 1996). Using \$5 of herbicide gives \$100 of increased maize yield in Striga-infested Kenya (Gressel et al. 1996a). Resistance could evolve in the parasitic weeds, not from introgression but by standard evolutionary processes, especially to the ALS-inhibiting herbicides. Without management strategies, resistant populations could predominate in as few as three years. Simple management strategies could delay this for $>12$ years (Gressel et al. 1996b).

\section{Rice/wild rices}

The risk of gene transfer from rice to red rice is high, precluding considering engineering. No one asked farmers. In paddy infested with highly competitive red rice 
(Pantona and Baker 1991) the total yield of rice is not reduced, but most of the red rice shatters, and is not harvested. Harvested red rice lowers the commercial grade of the rice. Farmers say: develop transgenic herbicide-resistant rice so they can have high yields until the gene gets transferred. Wild rices usually infest only paddy, other crops except soybean in roration with rice are not endangered. Red rice in soybeans are easily controlled by typical soybean herbicides that are usually used anyways in that crop (Griffin and Harger 1986; Khodayari et al. 1987).

\section{EPILOGUE}

Don't write off herbicide-resistant barleys, oats, sorghum and other truly high risk crops. These crops need herbicide resistances, both to control interbreeding weedy relations, and other weeds. Biotech may come up with solutions preventing pollen transfer: pollen specific excision systems, obligatory apomictic systems without pollen (Koltunow et al. 1995), requirements for more than one unlinked gene for resistance, tight or tandem linkage of the resistance gene to a crop gene that would be deleterious to a weed, infection of the crop with disarmed RNA viruses bearing resistance genes that are not pollen carried, to list some futuristic possibilities.

Much can be gained by using the right herbicide resistance genes for the right purposes in the right crops. Much can be lost by using the wrong genes in the wrong crop. One should be wary of those who present one-sided arguments or place environmental costs on herbicide use. They usually do not put a cost on not using herbicides. Not using herbicide costs human lives (starvation), decreases quality of life (insufficient food), costs economically as lost yield, and if cultivation is used instead, there is the environmental cost due to erosion. There are many parts of the world where weeds are the major constraints to crop production, and where herbicide-resistant crops can allow doubling crop production. An alternative is land abandonment.

The human mind is like a parachute, it is best used when open. We need an open mind to weigh where herbicide-resistant crops can be beneficial to food production and where detrimental. We must present regulators with scientific tools to weigh these issues, as too often they are swayed by know-nothing emotions on one side, or quick profit short term economic interests of industry on the other, to state the extremes. Like all powerful tools, certain herbicide-resistant crops have important long term roles in food production, others are contra-indicated. The same herbicide-resistant crop may have important uses in one agroecosystem and be foolish for another. One needs to ask many questions and perform careful monitoring.

\section{ACKNOWLEDGEMENTS}

Many colleagues are acknowledged for supplying information and insights into the uses and misuses of herbicide-resistant crops, but are not responsible for the author's views. The author's research on parasitic weeds is supported by USAID MERC grant HNE-0158-G-00-3060-00 and the Rockefeller Foundation. His work on developing transgenic herbicide-resistant wheat is supported by the Israel Ministry of Science. The author has the Gilbert de Botton Chair of Plant Sciences.

\section{REFERENCES}

Abayo, G.O., Ransom, J.K., Gressel, J. and Odhiambo, G.D., 1996.Striga hermonthica control with acetolactate synthase inhibiting herbicides seed-dressed to maize with target site resistance. Pp. 762-768In: Advances in Parasitic Weed Research, Junta de Andalucia.

Anonymous, 1995. Determination of environmental safety of Monsanto Canada Inc's Roundup herbicide tolerant Brassica napus Canola line GT73. Decision Document 95-02. Plant Products Division, Agriculture and Agri-Food Canada, Nepean Ontario $7 \mathrm{pp}$.

Baker, H.G., 1991. The continuing evolution of weeds. Econ. Bot. 45: 445-449.

Barrett, S.C.H., 1983. Crop mimicry in weeds. Econ. Bot. 37: 255-282.

Beversdorf, W.D., Hume, D.J. and Donnelly-Vanderloo, J.J., 1988. Agronomic performance of triazine-resistant and susceptible reciprocal Canola hybrds. Crop 
Sci. 28: 932-934

Boudry, P., Mörchen, M., Saumitou-Laprade, P., Vernet, P. and Van Dijk, H., 1993. The origin and evolution of weed beets: consequences for the breeding and release of herbicide-resistant transgenic sugar beets. Theor. Appl. Genet. 87: 471-478.

Charlesworth, D., 1988. Evidence for pollen competition in plants and its relationship to progeny fitness: A comment. Am. Nat. 132: 298-302.

Crawley, M.J., Hails, R.S., Rees, M., Kohn, D. and Buxton, J., 1993. Ecology of transgenic oilseed rape in natural habitats. Nature 363: 620-623.

Darmency, H., 1994. The impact of hybrids between genetically modified crop plants and their related species: introgression and weediness. Mol. Ecol. 3: 37-40.

Eijlander, R. and Stiekema, W.J., 1994. Biological containment of potato (Solanum tuberosum): outcrossing to the related wild species black nightshade (Solanum nigrum) and bittersweet (Solanum dulcamara). Sex Plant Reprod. 7: 29-40.

Gressel, J., 1988. Multiple resistances to wheat selective herbicides: New challenges to molecular biology. Oxford Surv. Plant Molec. Cell. Biol. 5:195-203.

Gressel, J., 1992a. Indiscriminate use of selectable markers-sowing wild oats. Trends Biotech. 10: 382.

Gressel, J., 1992b. The needs for new herbicide-resistant crops. Pp. 283-294 In: Achievements and Developments in Combating Pesticide Resistance, I. Denholm, A.L. Devonshire and D.W. Hollomon (Eds.). Elsevier, London.

Holm, L. Doll, J. Holm, E. Pancho J. and Herberger, J., 1997. Worlds Weeds: Natural Histories and Distributions. J. Wiley, New York. 1129 Pp.

Gressel, J. and Ben-Sinai, G., 1985. Low intra-specific competitive fitness in a triazine resistant, nearly nuclear-isogenic lines of Brassica napus. Plant Sci. 38: 29-32.

Gressel, J. and Joel, D., 1996. Seed dressing compositions. (Israel Patent Application).

Gressel, J. and Kleifeld, Y., 1994. Can wild species become problem weeds because of herbicide resistance?Brachypodium distachyon: a case study.Crop Prot. 13:563566

Gressel, J., Aviv, D. and Perl, A., 1989. Methods of producing herbicide resistant plant varieties and plants produced thereby. U.S. Patent No. 4,795,705.

Gressel, J., Ransom, J.K. and Hassan, E.A., 1996a. Biotech-derived herbicide- resistant crops for third world needs. Ann. New-York Acad. Sci. 792: 140-153.

Gressel, J., Segel, L.E. and Ransom, J.K., 1996b. Managing the delay of evolution of herbicide resistance in parasitic weeds. Intl. J. Pest Management 42:113-129.

Griffin, J.L. and Harger, T.R., 1986. Red rice (Oryza sativa) and junglerice (Echinochloa colonum) control in solid-seeded soybeans (Glycine max). Weed Sci. 34: 582-586.

Islam, A.K.M.R. and Powles, S.B., 1991. Attempts to transfer paraquat resistance from barley grass (Hordeum glaucum Steud.) to barley and wheat. Weed Res. 31: 395399.

Joel, D.M., Kleifeld, Y., Losner-Goshen, D., Herzlinger, G. and Gressel, J., 1995. Transgenic crops against parasites. Nature 374: 220-221.

Kareiva, P., Parker, I.M. and Pascual, M., 1996. Can we use experiments and models in predicting the invasiveness of genetically engineered organisms?Ecology 77: 16701675.

Kerlan, M.C., Chevre, A.M. and Eber, F., 1993. Interspecific hybrids between a transgenic rapeseed (Brassica napus) and related species: cytogenetical characterization and detection of the transgene. Genome 36:1099-1106.

Khodayari, K., Smith, Jr., R.J. and Black, H.L., 1987. Red rice (Oryza sativa) control with herbicide treatments in soybeans (Glycine max). Weed Sci. 35: 127-129.

Kling, J. 1996., Could transgenic supercrops one day breed superweeds? Science 274: $180-181$.

Lefol, E., Fleury, A.and Darmency, H. 1996. Gene dispersal fron transgenic crops II. Hybridization between oilseed rape and the wild hoary mustard.Sex. Plant Reprod. 9: $189-196$.

Koltunow, A.M., Bicknell, R.A. and Chaudhury, A.M. 1995. Apomixis: Molecular strategies for the generation of genetically-identical seeds without fertilization.Plant Physiol. 108:1345-1352. 
Lewis, M.W., 1992. Green delusions: An environmentalist critique of radical environmentalism. Duke Univ. Press. 288pp.

Malik R. K. and Singh, S. 1995. Littleseed canarygrass (Phalaris minor) resistance to isoproturon in India. Weed Tech. 9: 419-425.

Mallory-Smith, C.A., Hansen, J. and Zemetra, R.S., 1996. Gene transfer between wheat and Aegilops cylindrica. Pp. 441-445 In: Second Intern. Weed Control Cong. Copenhagen.

McMullan, P.M., Daun, J.K. and DeClercq, D.R., 1994. Effect of wild mustard (Brassica kaber) competition on yield and quality of triazine-tolerant and triazine-susceptible canola (Brassica napus and Brassica rapa). Can. J. Plant Sci. 74: 369-374.

Mikkelsen, T.R., Andersen, B. and Jorgensen, R.B., 1996. The risk of crop transgene spread. Nature 380: 31.

Moody, M.E. and Mack, R.N., 1988. Controlling the spread of plant invasions: the importance of nascent foci. J. Appl. Ecol. 25: 1009-1021.

Moss, S., 1992. Herbicide resistance in the weedAlopecurus myosuroides(blackgrass): the current situation, Pp. 28-47In: Achievements and Developments in Combating Pesticide Resistance, I. Denholm, A.L. Devonshire and D.W. Hollomon (Eds); Elsevier, London.

Mulcahy, D.L. and Mulcahy, G.B., 1987. The effects of pollen competition.Am. Sci. 75: 44-50.

Pantone, D.J. and Baker, J.B. Weed-crop competition models and response-surface analysis of red rice competition in cultivated rice: A review. Crop Sci. 31:11051110

Powles, S.B. and Holtum, J.A.M.,(Eds.), 1994. Herbicide Resistance in Plants: Biology and Biochemistry. Lewis, Boca Raton, $353 \mathrm{pp}$.

Rissler, J. and Mellon, M., 1993. Perils amidst the promise- ecological risks of transgenic crops in a global market. Union of Concerned Scientists, Cambridge Mass. 92 pp..

Sindel, B.M., 1997. Outcrossing of transgenes to weedy relatives. Pp 43-81 In: Commercialisation of Transgenic Crops: Risk, Benefit and Trade Considerations. G.D. McLean, P.M. Waterhouse G. Evans and M.J. Gibbs (Eds), Coop. Res. Center for Plant Sci. and Bur. of Resource Sci., Canberra.

Singh S., Kirkwood R. C. and Marshall, G. 1997 Enhanced degradation by cytochrome $\mathrm{P}-450$ is the mechanism of resistance in Phalaris minor biotypes. WSSA Abstracts 37:167.

Smeda, R.J., Hasagawa, P.M., Goldsbrough, P.B., Singh, N.K. and Weller, S.C., 1993. A serine-to-threonine substitution in the triazine herbicide-binding protein in potato cells results in atrazine resistance without impairing productivity. Plant Physiol. 103: 911-917.

Somers, D.A., Rines, H.W., Gu, W., Kaeppler, H.F. and Bushnell, W.R. 1992. Fertile transgenic oat plants. Bio/Technology 10: 1589-1594.

Souza-Machado, V. 1982. Inheritance and breeding potential of triazine tolerance and resistance in plants. Pp. 257-273In: Herbicide Resistance in Plants. H. LeBaron and J. Gressel, (Eds.) Wiley, NYC.

Stephenson, A.G., Winsor, J.A., Schlichting, C.D. and Davis, L.E. 1988 Pollen competition: nonrandom fertilization and progeny fitness: a reply to Charlseworth. Am. Nat. 132: 303-308.

Streber, W.R. and Willmitzer,L. 1989. Transgenic tobacco plants expressing a bacterial detoxifying enzyme are resistant to 2,4-D, Bio/Technology 7: 811-816.

Surov, T., Aviv, D., Aly, R., Joel, D.M., Goldman-Guez, T. and Gressel, J., 1997. Generation of transgenic asulam-resistant potatoes to facilitate eradication of parasitic broomrapes (Orobanche spp.), with thesul gene as the selectable marker. (submitted).

Timmons, A.M., Charters, Y.M., Crawford, J.W., Burn, D., Scott, S.E., Dubbels, S.J., Wilson, N.J., Robertson, A., O’Brien, E.T., Squire, G.R. and Wilkinson, M.J., 1996. Risks from transgenic crops. Nature 380: 487. 
